\title{
PENERAPAN STRATEGI BELAJAR PQ4R UNTUK MENINGKATKAN HASIL BELAJAR IPS DI KELAS V DI SDN 1 KALU-KALUKU
}

\author{
Jemmi $^{1)}$, I Ketut Suardika ${ }^{2)}$ \\ 1) SDN 1 Kalu-Kaluku, Kolaka Utara, Indonesia \\ ${ }^{2)}$ Jurusan PGSD, Universitas Halu Oleo, Kendari, Indonesia \\ email: jemminahda@yahoo.com
}

\begin{abstract}
Abstrak: Tujuan dari penelitian ini adalah untuk meningkatkan hasil belajar IPS materi sejarah kerajaan yang bercorak Islam melalui penerapan model pembelajaran strategi PQ4R pada siswa kelas V SD Negeri 1 Kalu-Kaluku. Prosedur penelitian mengikuti prosedur penelitian tindakan kelas yaitu; (a) perencanaan, (b) pelaksanaan tindakan, (c) observasi dan evaluasi, dan (d) refleksi. Teknik pengumpulan data menggunakan lembar observasi aktivitas dan evaluasi tes siklus. Teknik analisis data menggunakan analisis deskriptif. Indikator keberhasilan dalam penelitian ini terdiri dua yaitu dari segi proses dan hasil. Hasil analisis penelitian menunjukkan bahwa persentase aktivitas belajar siswa, persentase aktivitas mengajar guru dan ketuntasan hasil belajar siswa mengalami peningkatan dari siklus I sampai pada siklus II. Persentase aktivitas belajar siswa pada siklus I pertemuan pertama adalah $73,33 \%$ dan pada pertemuan kedua adalah 93,33\% sedangkan pada siklus II persentase aktivitas belajar siswa pertemuan pertama adalah $93,33 \%$ dan pertemuan kedua adalah $100 \%$. Persentase aktivitas mengajar guru pertemuan pertama adalah $73,33 \%$ dan pertemuan kedua adalah $86,66 \%$ sedangkan persentase aktivitas mengajar guru pada siklus II pertemuan pertama adalah $93,33 \%$ dan pertemuan kedua adalah $100 \%$. Hasil belajar siswa siklus I menunjukkan persentase ketuntasan sebesar $70 \%$ dan pada siklus II persentase ketuntasan meningkat menjadi $100 \%$.
\end{abstract}

Kata kunci: strategi belajar PQ4R; hasil belajar

\section{THE IMPLEMENTATION OF PQ4R LEARNING STRATEGIES TO IMPROVE STUDENT LEARNING OUTCOMES IN IPS CLASS V IN SDN 1 KALU-KALUKU}

\begin{abstract}
The aim of the study was to improve social studies learning outcomes in Islamic kingdom history material through the application of the PQ4R strategy learning model for fifth grade students of SD Negeri 1 Kalu-Kaluku. The research procedure followed the classroom action research procedure, namely; (a) planning, (b) implementing actions, (c) observation and evaluation, and (d) reflection. Data collection techniques used activity observation sheets and cycle test evaluations. The data analysis technique used descriptive analysis. There are two indicators of success in this study, namely in terms of process and outcome. The results of the research analysis showed that the percentage of student learning activities, the percentage of teacher teaching activities and the completeness of student learning outcomes had increased from cycle I to cycle II. The percentage of student learning activities in the first cycle of the first meeting was $73.33 \%$ and the second meeting was $93.33 \%$, while in the second cycle the percentage of student learning activities in the first meeting was $93.33 \%$ and the second meeting was $100 \%$. The percentage of teacher teaching activities in the first meeting was $73.33 \%$ and the second meeting was $86.66 \%$, while the percentage of teacher teaching activities in the second cycle of the first meeting was $93.33 \%$ and the second meeting was $100 \%$. Student learning outcomes in cycle I showed the percentage of completeness by $70 \%$ and in cycle II the percentage of completeness increased to $100 \%$.
\end{abstract}

Keywords: $P Q 4 R$ learning strategy; learning outcomes 


\section{Pendahuluan}

Pembelajaran Ilmu Pengetahuan Sosial (IPS) menekankan pada pemberian pengalaman langsung untuk mengembangkan kompetensi agar menjelajahi dan memahami alam sekitar secara ilmiah. Peranan guru dalam memfasilitasi siswa untuk mencapai standar kompetensi dan kompetensi dasar dilandasi oleh pemberdayaan siswa untuk membangun kemampuan, bekerja ilmiah dan membangun pengetahuan sendiri.

Proses pembelajaran di sekolah merupakan serangkaian kegiatan yang secara sadar telah tersusun dan terencana dengan baik. Dengan adanya perencanaan yang baik, akan mendukung keberhasilan guru dalam proses pelaksanaan pembelajaran. Di dalam proses pembelajaran, guru memiliki peranan yang sangat penting dan strategis dalam menciptakan suasana belajar yang efektif dan efisien, oleh karena itu guru dituntut harus memiliki kemampuan dalam perancangan dan pelaksanaan pembelajaran. Kemampuan tersebut sangat menentukan suasana belajar yang efektif dan efisien serta ketercapaian tujuan pembelajaran. Perancangan pembelajaran merupakan hal yang harus dipersiapkan oleh guru sebelum pelaksanaan pembelajaran diantaranya berupa penentuan model dan metode atau strategi pembelajaran.

Penentuan model dan metode atau strategi pembelajaran yang tidak tepat dalam proses pembelajaran berdampak pada hasil belajar siswa yang kurang optimal. Hal ini dapat dilihat dari hasil belajar siswa yang masih kurang dalam mempelajari konsep-konsep IPS. Seperti yang terjadi pada siswa kelas V SD Negeri 1 Kalu-Kaluku selama dua thun terakhir menunjukkan bahwa hasil belajar siswa materi kerajaan yang bercorak Islam yang masih di bawah standar rata-rata, yakni kurang dari nilai 65. Pada semester ganjil tahun pelajaran 2014/1015 ketuntasan belajar siswa mencapai 56\% dengan rata-rata 54,5 dan pada semester ganjil tahun pelajaran 2015/2016 ketuntasan belajar siswa sebesar 68\% dengan rata-rata 60 . Berdasarkan observasi awal, disimpulkan bahwa rendahnya hasil belajar siswa disebabkan beberapa hal diantaranya: (1) siswa belum diajari teknik dan strategi belajar yang efektif dan efisien dalam mempelajari pengetahuan deklaratif dan pengetahuan prosedural, dan (2) siswa mudah lupa pada materi-materi yang bersifat abstrak sehingga prestasinya belum maksimal.

Melihat semua permasalahan yang ada, perlu dicari solusi dalam menentukan strategi yang tepat, untuk lebih mengoptimalkan hasil belajar siswa kelas V SD Negeri 1 Kalu-Kaluku khususnya materi kerajaan yang bercorak Islam. Untuk itu perlu adanya inovasi pengajaran berupa penerapan strategi-strategi belajar (Learning Strategy) untuk memecahkan masalah belajar siswa sehingga hasil belajar siswa dapat meningkat. Jenis strategi belajar yang tepat untuk digunakan adalah strategi belajar PQ4R (Preview, Question, Read, Recite, Reflection, Review). Menurut Thomas F. Robinson dalam Ningsih, dkk (2014, p.2) mengemukakan bahwa Strategi ini merupakan strategi belajar elaboratif yang digunakan untuk meningkatkan kinerja daya ingat atau memori dalam memahami substansi teks atau materi dalam buku.Strategi belajar PQ4R dapat membantu siswa mengingat apa yang mereka baca. Sesuai dengan singkatannya, PQ4R diawali dengan membaca sepintas kemudian mengemukakan pertanyaan, setelah itu mengulangi membaca materi, merefleksi dan melakukan tanya jawab sendiri serta mengulang secara menyeluruh. Melakukan preview atau membaca sepintas dengan cepat dan mengajukan pertanyaan-pertanyaan sebelum membaca mengaktifkan pengetahuan awal dan mengawali proses pembuatan hubungan antara informasi baru dengan apa yang telah diketahui. Strategi belajar PQ4R dapat menjadikan siswa tidak lagi merasa bosan dan menjadikan pembelajaran lebih menyenangkan. Melalui strategi ini diharapkan hasil belajar siswa dapat meningkat karena dapat membantu siswa mengingat apa yang mereka baca dan peroleh selama dalam proses pembelajaran di kelas. Menurut Linayaningsih (2011, p.76) mengemukakan bahwa metode PQ4R merupakan strategi belajar yang diberikan kepada siswa. Metode PQ4R membantu siswa memahami dan mengingat materi yang dibaca. 
Strategi pembelajaran Preview, Question, Read, Reflect, Recite, Dan Review (PQ4R), guru sebagai pengajar mampu menciptakan pembelajaran aktif, kreatif dan inovatif, karena tidak dapat dipungkiri, tujuan pembelajaran yang sesungguhnya adalah bagaimana mentransformasikan ilmu kepada siswa agar dapat memahami pelajaran dengan baik (Wangka \& Mustahidang, 2016, p.70). Melalui langkah-langkah strategi PQ4R (Preview Question Read Reflect Recite Review) kegiatan membaca siswa lebih terarah dengan tujuan jelas yaitu menemukan informasi dari bacaan sesuai dengan pertanyaan yang telah dibuat sebelum membaca (Sinaga. 2017, p.4)

Berdasarkan latar belakang di atas, maka peneliti tertarik melakukan penelitian tindakan kelas dengan judul "Penerapan Strategi Belajar PQ4R untuk Meningkatkan Hasil Belajar Siswa pada Mata Pelajaran IPS di Kelas V SD Negeri 1 Kalu-Kaluku Kabupaten Kolaka Utara“.

Hasil penelitian yang dilakukan oleh Nurhasanah (2010), dengan judul penelitian "Meningkatkan hasil belajar siswa pada mata pelajaran IPS melalui model pengajaran langsung dan strategi belajar PQ4R (Preview, Question, Read, Refleksi, Recite dan Review) di kelas V SD Negeri 1 Ambolodangge" yang menyimpulkan bahwa terdapat peningkatan hasil belajar IPS siswa yang meliputi keaktifan dan perhatian belajar siswa dari $75 \%$ pada siklus I dan $85 \%$ pada siklus II. Hasil belajar juga mengalami peningkatan dari $64,5 \%$ pada siklus I dan $85,5 \%$ pada siklus II.

Hasil penelitian yang dilakukan oleh Meilissa Aritonang dengan judul Penerapan Strategi PQ4R (Preview, Question, Read, Reflect, Recite, Review) Terhadap Hasil Belajar Siswa pada Materi mengenal benua pada siswa kelas IV SDN 1 Wolasi T.P 2011/2012 yang menyimpulkan bahwa hasil belajar siswa dapat ditingkatkan melalui Penerapan Strategi PQ4R dengan persentase ketuntasan klasikal pada akhir siklus tindakan sebesar $85 \%$.

Strategi pembelajaran Preview, Question, Read, Reflect, Recite, Review dirancang secara matang dan dilaksanakan secara tepat diharapkan dapat mendorong siswa lebih dapat meningkatkan persiapan dalam menerima pelajaran. Peningkatan motivasi belajar siswa juga diharapkan membawa dampak positif yaitu peningkatan hasil belajar siswa.

Masalah dalam penelitian adalah apakah penerapan model pembelajaran strategi PQ4R dapat meningkatkan hasil belajar IPS materi sejarah kerajaan yang bercorak Islam pada siswa kelas V SD Negeri 1 Kalu-Kaluku? Tujuan penelitian adalah untuk untuk meningkatkan hasil belajar IPS materi sejarah kerajaan yang bercorak Islam melalui penerapan model pembelajaran strategi PQ4R pada siswa kelas V SD Negeri 1 Kalu-Kaluku. Penelitian ini diharapkan dapat memberikan manfaat bagi guru, siswa, sekolah dan penelitian lainnya.

\section{Metode}

Jenis penelitian ini adalah Penelitian Tindakan Kelas. Penelitian tindakan kelas adalah kegiatan mengumpulkan, mengolah, menganalisis dan menyimpulkan data untuk menentukan tingkat keberhasilan jenis tindakan yang dilaksanakan oleh guru dalam proses pebelajaran (Yuliawati, 2012:17). Penelitian ini dilaksanakan pada semester ganjil, tahun ajaran 2016/2017 di Kelas V SDN 1 Kalu-Kaluku. Subyek penelitian ini adalah guru dan siswa kelas V SDN 1 Kalu-Kaluku yang berjumlah 10 orang siswa terdiri dari 4 siswa lakilaki dan 6 orang siswa perempuan. Faktor yang diteliti dalam penelitian ini adalah 1) faktor siswa, 2) Faktor guru dan faktor 3) hasil belajar. Penelitian Tindakan Kelas ini dilaksanakan dalam 2 (dua) siklus. Adapun prosedur penelitian tindakan ini meliputi: (1) Perencanaan, (2) Pelaksanaan Tindakan, (3) Observasi dan Evaluasi, dan (4) Refleksi dalam setiap siklus. Data yang didapatkan dalam penelitian ini adalah data kualitatif dan data kuantitatif. Data kuantitatif diperoleh dari tes hasil belajar siswa sedangkan data kualitatif diperoleh dari hasil observasi aktivitas guru dan siswa dalam proses pembelajaran. 
Analisis data dalam penelitian ini adalah statistik deskriptif untuk menghitung rata-rata perolehan nilai siswa, persentase ketuntasan klasikal, persentase ketuntasan keberhasilan aktivitas mengajar guru dan persentase keberhasilan aktivitas belajar siswa yang dicapai setelah proses pembelajaran berlangsung pada setiap siklus.

Keberhasilan pembelajaran siswa dihitung berdasarkan skor perolehan pada setiap tahap pembelajaran. Jumlah skor total yang diperoleh siswa kemudian dibagi dengan jumlah skor maksimum dikalikan dengan seratus persen. Indikator keberhasilan penelitian adalah Penelitian ini dikatakan berhasil jika $80 \%$ siswa telah mencapai KKM yang ditetapkan sekolah untuk nilai mata pelajaran IPS sebesar 65.

\section{Hasil}

\section{Hasil Belajar Siswa}

Hasil belajar siswa siklus I menunjukkan persentase ketuntasan sebesar $70 \%$ dan pada siklus II persentase ketuntasan meningkat menjadi $100 \%$.

\section{Aktivitas Mengajar Guru}

Persentase aktivitas mengajar guru pertemuan pertama adalah $73,33 \%$ dan pertemuan kedua adalah $86,66 \%$ sedangkan persentase aktivitas mengajar guru pada siklus II pertemuan pertama adalah $93,33 \%$ dan pertemuan kedua adalah $100 \%$.

\section{Aktivitas Belajar Siswa}

Persentase aktivitas belajar siswa pada siklus I pertemuan pertama adalah 73,33\% dan pada pertemuan kedua adalah 93,33\% sedangkan pada siklus II persentase aktivitas belajar siswa pertemuan pertama adalah $93,33 \%$ dan pertemuan kedua adalah $100 \%$.

\section{Pembahasan}

\section{Hasil belajar Siswa}

Berdasarkan hasil belajar siswa pada siklus I menunjukkan bahwa penguasaan siswa secara klasikal terhadap materi sebesar $70 \%$ atau 7 siswa yang memperoleh nilai $\geq 70$ dengan nilai rata-rata 68,5.

Pada siklus II hasil belajar siswa dengan nilai rata-rata klasikal 84 dengan ketuntasan $100 \%$ karena semua siswa berjumlah 10 orang telah tuntas belajar. Hal ini menunjukkan hasil belajar siswa telah mengalami peningkatan karena melihat indikator keberhasilan dalam penelitian ini sudah tercapai yaitu minimal $80 \%$ siswa telah mencapai nilai $\geq 70$ sesuai kriteria ketuntasan minimal (KKM) pada SDN 1 Kalu-Kaluku, ini disebabkan karena siswa sangat antusias menerima pembelajaran model strategi PQ4R dengan materi sejarah kerajaan bercorak islam, semua siswa sudah mampu bekerja sama dalam kelompoknya dan telah memahami dan mengerti tentang pembelajaran strategi PQ4R, ketika guru menyampaikan model pembelajaran yang akan di gunakan adalah model pembelajaran strategi PQ4R, siswa terlihat sangat senang.

Bertitik tolak dari hasil tindakan siklus II dengan nilai rata-rata klasikal 84 dengan ketuntasan $100 \%$. ini menunjukkan hasil belajar siswa telah mengalami peningkatan, maka penggunakan model pembelajaran strategi PQ4R dapat diterapkan.

\section{Aktivitas Mengajar Guru}

Berdasarkan hasil observasi aktivitas guru dalam pembelajaran dengan menerapkan model pembelajaran strategi PQ4R pada setiap siklus mengalami peningkatan, yakni siklus I yaitu 93,33\% (pertemuan 2) dan meningkat pada siklus II yaitu 100\% (pertemuan 2). Selain itu juga hasil observasi guru yaitu dapat memotivasi siswa, menambah semangat siswa belajar 
terhadap kelompoknya, membuat siswa senang dalam belajar sambil. Hal ini menunjukkan bahwa kemampuan guru dalam melaksanakan pembelajaran strategi PQ4R sudah efektif.

\section{Aktivitas Belajar Siswa}

Berdasarkan hasil observasi dengan penerapan model pembelajaran strategi PQ4R pada siklus I yaitu $86,67 \%$ (pertemuan 2) pada siklus II mengalami peningkatan menjadi $100 \%$ (pertemuan 2). Hal ini dapat pula dilihat dari tahapan aktivitas belajar siswa melalui penerapan model strategi PQ4R dapat ditingkatkan kualitas pembelajarannya. Pada saat dilaksanakan pembelajaran siswa antusias dan berlomba-lomba untuk maju kedepan kelas untuk mewakili kelompoknya mempresentasikan hasil kerja kelompoknya. Hal ini sesuai dengan salah satu ciri yang dikemukakan oleh Hartadji (2001, p.34) adalah adanya penghargaan yang lebih berorientasi pada kelompok dari pada individu akan membuat siswa senang. Penghargaan/penguatan yang dimaksud berupa pemberian juara 1, 2, 3 yang disertai tepukan tangan dari seluruh siswa, pemberian penghargaan/penguatan ini adalah untuk memacu semangat siswa dalam belajar. Menururt Hamalik dalam (Nupiksani. 2015, p.15) bahwa hasil belajar menunjukkan kepada prestasi belajar, sedangkan prestasi belajar itu merupakan indikator adanya derajat perubahan tingkah laku siswa.

\section{Simpulan}

Berdasarkan hasil observasi, evaluasi dan refleksi pada setiap tindakan kelas maka dapat disimpulkan bahwa Penerapan Model Pembelajaran Strategi PQ4R dengan Materi Sejarah kerajaan bercorak islam dapat meningkatkan hasil belajar PKn siswa kelas V SD Negeri 1 Kalu-Kaluku. Hal ini ditunjukkan dengan peningkatan kegiatan pembelajaran sebagai berikut:

1. Peningkatan hasil belajar siswa kelas V SD Negeri 1 Kalu-Kaluku yaitu dapat di lihat dari hasil belajar siklus I siswa memperoleh ketuntasan klasikal $70 \%$ dan meningkat pada siklus II dengan ketuntasan klasikal mencapai $100 \%$.

2. Aktivitas belajar siswa mengalami peningkatan dengan persentase siklus I pertemuan kedua mencapai $86,67 \%$ dan pada siklus II pertemuan kedua mencapai $100 \%$.

3. Aktivitas mengajar guru mengalami peningkatan dengan persentase siklus I sebesar 93,33\% (pertemuan kedua) dan meningkat menjadi 100\% (pertemuan kedua) pada siklus II.

\section{Referensi}

Linayaningsih, Fitria. (2011). Metode PQ4R (Preview, Question, Read, Reflect, Recite,Review) Untuk Meningkatkan Prestasi Belajar Pendidikan Kewarganegaraan. Majalah Ilmiah Informatika Vol. 2 No. 2. 75-86.

http://www.unaki.ac.id/ejournal/index.php/majalah-ilmiah-informatika/article/ view/41

Ningsih, Winda Irma, Imam Muchtar, \& Rahayu. (2014). Peningkatan Aktivitas dan Hasil Belajar Siswa Melalui Penerapan Strategi Belajar PQ4R (preview, question, read, reflect, recite, review) Dalam Pembelajaran Pkn Pokok Bahasan Organisasi Kelas VA di SDN Jember Kidul 04. Artikel Ilmiah Mahasiswa 2014, I (1): 1-5. http://repository.unej.ac.id/handle/123456789/64191 
Nurhasana. (2010). Meningkatkan hasil belajar siswa pada mata pelajaran IPS melalui model pengajaran langsung dan strategi belajar PQ4R (Preview, Question, Read, Refleksi, Recite dan Review) di kelas V SD Negeri 1 Ambolodangge. FKIP. Unhalu. Kendari.

Nupiksani, Sri. (2015). Meningkatkan Hasil Belajar IPS Melalui Penerapan Model Pembelajaran Group Investigation Pada Siswa Kelas VI SDN Rejoagung 01 Kecamatan Semboro Kabupaten Jember. Pancaran, Vol. 4, No. 4, hal 13-24. https://jurnal.unej.ac.id/index.php/pancaran/article/download/2174/1768/Nur M. (2000). Pembelajaran Kooperatif. Surabaya: Universitas Press UNESA.

Sinaga, Siti (2016). Penerapan Strategi PQ4R (Preview, Question, Read, Reflect, Recite, Review) Untuk Meningkatkan Kemampuan Membaca Pemahaman Siswa Sekolah Dasar. S1 Thesis. Universitas Pendidikan Indonesia. http://repository.upi.edu/id/eprint/25471

Sudjana N. (2002). Penilaian Hasil Proses Belajar Mengajar. Bandung: PT. Remaja Rosdakarya.

Suparno, Paul. (2008). Riset Tindakan untuk Pendidik. Jakarta: Grasindo

Usman U. M. dan Setiawati. (2001). Menjadi Guru Profesional. Bandung: PT. Remaja Rosdakarya.

Wangka, Astriani \& Mustahidang Usman. (2016). Penerapan Strategi Pembelajaran PQ4R (Preview, Question, Read, Reflect, Recite, Dan Review) Dalam Meningkatkan Prestasi Belajar PAI. Jurnal Tarbawi Volume 1, No 1. 68-76. DOI: https://doi.org/10.26618/jtw.v1i1.359

Yuliawati F. (2012). Penelitian Tindakan Kelas untuk Tenaga Pendidik Profesional. Yogyakarta: Pedagogia. 